\title{
Chemical, Nutritional and Microbiological Evaluation of Some Egyptian Soft Cheeses
}

\author{
${ }^{1 * G h a d a, ~ Z . ~ A . ~ A ., ~}{ }^{2 *}$ Alia, M. H., ${ }^{3 * * S o h a, ~ A l-S ., ~}{ }^{4 * M a g d y, ~ N . ~ A ., ~ a n d ~}{ }^{5 *}$ Mohammed, F. S., \\ ${ }^{1}$ Lecture of Biochemistry, ${ }^{2}$ Lecture of Food Hygiene, ${ }^{3}$ Lecture of Nutrition, ${ }^{4}$ Associate Prof of \\ Ecological Sciences, ${ }^{5}$ Prof of Microbiology. *The National Nutrition Institute. \\ **Suez Canal University.
}

\begin{abstract}
Milk and dairy products is considered the most complete foodstuff that provide human either infants or adults with most of their vital needs. Milk and cheese have high nutritive value due to its high content of protein, fat, minerals especially calcium $\left(\mathrm{Ca}^{2+}\right) \&$ phosphorous, and vitamins. Two hundred samples produced and sold in Egypt during 2001-2003 were collected from allover the country. The cheese samples were subjected to microbiological and chemical analysis. Samples were microbiologically tested for total aerobic bacterial count (TABC), Colifrm, Escherichia coli (E. coli), Staphylococcus aureus, mould and yeast, salmonella and shigella, and listeria species. Protein, fat, carbohydrates, moisture, ash, lactose, Calcium $(\mathrm{Ca})$, phosphorous $(\mathrm{P})$ and $\mathrm{Ca} / \mathrm{P}$ were evaluated. The analysis showed that total aerobic bacterial count did not exceed $1.4 \times 10^{5} \pm 1.7 \times 10^{5}$ cells/gm, which is close to what allowed by the Standard Egyptian Guidelines (2001) and $47.5 \%$ of the tested cheese are free from coliform bacteria and Escherichia coli. Ninety-eight and half percent, $97 \%, 97 \%$ and $91.5 \%$ of the tested cheese (kareish, feta, thalaga, double cream respectively), either made in plant or home or farmers' cheese sample have zero Staphylococcus aureus count or mould and yeast; or salmonella and shigella, or listeria species respectively, i. e. free from them. Double cream cheese has the lowest protein content $(7.79 \pm 0.78 \mathrm{gm} \%)$ while kareish cheese has the highest protein content $(19.99 \pm 1.32 \mathrm{gm} \%)$, but for fat content the opposite is true, double cream cheese have the highest fat content $(24.56 \pm 1.78 \mathrm{gm} \%)$ while kareish cheese have the lowest fat content $(3.87 \pm 0.97 \mathrm{gm} \%)$. Feta cheese has high ash content while kareish cheese has the highest moisture content with the lowest ash content $(68.97 \pm 1.86 \& 1.81 \pm 0.47$ gm\% respectively). Lactose content varies widely from $1.50 \pm 0.26$ (double cream cheese) to $3.25 \pm 0.50$ (feta cheese). Kareish cheese has higher content of calcium and phosphorous $(641.1 \pm 49.21 \mathrm{mg} \%$, $431.18 \pm 37.21 \mathrm{mg} \%$ respectively) than the remaining types of cheese. Calcium \& phosphorous content of kareish cheese is almost the double content of the double cream cheese. Feta cheese has higher $\mathrm{Ca} / \mathrm{P}(1.65 \pm 0.19)$ while thalaga and double cream has lower $\mathrm{Ca} / \mathrm{P}(1.34 \pm 0.13 \&$ $1.37 \pm 0.20)$. Each $100 \mathrm{gm}$ of soft cheese can provide children $(1-8 \mathrm{y}) \&$ adult $(9-\geq 50 \mathrm{y})$ from $39.78 \%$ \& $24.48 \%$ to128.22 \% \& $64.11 \%$ of their Ca Dietary Reference Intake and this from double cream cheese and kareish cheese respectively.
\end{abstract}

\section{Introduction}

Milk and dairy products represent the most popular foodstuff that provide human with most of their vital needs. In developing countries milk and dairy products industry represent a powerful economic income. In Egypt this industry represent $35 \%$. Milk and cheese have high nutritive value due to its high content of protein, fat, minerals especially calcium
$\left(\mathrm{Ca}^{2+}\right)$, phosphorous, and vitamins (Badawi, 1996; and Food composition tables, 1998). Cheese is made from milk through clotting using renin or through souring of the milk (Miller et al., 1999). The used milk is either raw or pasteurized. Cheeses are made either in large planning that is well equipped or in small planning or in farmers' home or in unlicensed factories. The last three places 
especially the unlicensed one is a disaster. Manufacturing cheese in these places make them more labile to contamination and any fault during manufacture may lead to series hazards (Al-Ashmawy et al., 1994). Microorganisms may gain access to cheese during process; handling and distribution since milk provide a high nutritive, favorable media for the growth and multiplication of such organisms. Many food poisoning outbreaks may be due to using milk from diseased animals with infection of bacterial origin or manufacturing in contaminated places or from the workers themselves. Ingestion of certain microorganism can be detrimental to human health (UNEP, 1992). Bacteria that most frequently cause mastitis can be divided into two large groups based on the source of the bacteria: contagious pathogens as Staphlyococcus aureus and environmental pathogens as coliform bacteria and environmental streptococci species. Milk and dairy products can provide us with a considerable amount of the recommended dietary intake of calcium. Calcium plays an important role in teeth building and many diseases as cardiovascular, osteoporosis and hypertension. Calcium from dairy foods had a large effect on systolic blood pressure. It reduces it in hypertensive not normotensive by $2 \mathrm{mmHg}$ for every two cups of milk, $\approx 730 \mathrm{mg} \mathrm{Ca}$, consumed per day. No association was observed between non-dairy $\mathrm{Ca}$ intake and blood pressure (Ackley et al., 1983; Reed et al., 1985; and Cappuccino et al., 1995). Osteoporosis is increasing and spreading fast especially in women and it represent a major public health (Riggs and Melton, 1995; and Looker et al., 1997).

\section{Aim of the Work}

The aim of this study was to evaluate the nutritional, chemical and microbiological quality of different soft cheeses produced and sold in Egypt during 20012003 to determine the amount of total aerobic bacterial count (TABC), Colifrm, Escherichia coli (E. coli), Staphylococcus aureus, mould and yeast, salmonella and shigella, and listeria species and to evaluate protein, fat, carbohydrates, moisture, ash, lactose, Calcium $(\mathrm{Ca})$, phosphorous $(\mathrm{P})$ and $\mathrm{Ca} / \mathrm{P}$. The microbiological and chemical contents were reviewed with WHO and Egyptian standards guidelines to see if it fit for human consumption.

\section{Materials and Methods}

\section{Sampling}

Two hundred samples produced and sold in Egypt during 2001- 2003 were collected from allover the country. The cheese samples were subjected to microbiological and chemical analysis.

\section{Microbiological Analysis}

Samples were microbiologically tested for total aerobic bacterial count (TABC), Colifrm, Escherichia coli (E. coli), Staphylococcus aureus, mould and yeast, salmonella and shigella, and listeria species. They were investigated according to ICMSF, 1996; James and Natalie (2002) and Ahmed and Carolyn (2003).

\section{Chemical Analysis}

Protein, fat, carbohydrates, moisture, ash and lactose were determined according to AOAC (1990). Calcium (Ca) was measured in the ash using atomic absorption, Unicam 929 (AOAC, 1981). Phosphorous (P) was estimated colorimetrically in the ash according to (AOAC, $1981)$ and $\mathrm{Ca} / \mathrm{P}$ was calculated.

\section{Results and Discussion}

Plants construction affect microbial contamination, so it is important that clean air and water are available and the used equipments and the contact surfaces are always clean and do not react with the products. The plants'soil can be source of contamination if proper and effective sanitation are not present. Each processing facility, equipments, raw materials and products should go daily through microbial analysis. Also the workers in this field should be carefully chosen with a good care of them and ensure that they apply health rules (Marriott, 1999).

Data of table (1) showed total aerobic bacterial count of some soft Egyptian 
cheese. Forty Nine percent (49 \%, (98/200)) of the tested cheese, either made in plant $(81 / 100)$ or home or farmers' made (17/100), have zero total aerobic bacterial count. The remaining tested cheese samples $(102 / 200,51 \%)$ either made in plant $(19 / 100)$ or home or farmers' made (83/100) having total aerobic bacterial counts range from $42.33 \pm 7.51$ to $1.4 \times 10^{5} \pm 1.7 \times 10^{5}$ cells/gm which is close to what allowed by the Standard Egyptian Guidelines (2001) and than the maximum limit proposed by Ottogalli et al. (1985). They proposed a maximum limit of $\mathrm{X}^{4} 0^{4}$ to $\mathrm{X} 10^{5}$ cells $/ \mathrm{gm}$. From $60 \%$ (thalaga) to Ninety percent (kareish \& Feta) of the tested plant made cheese were free of aerobic bacteria and from 5\% (thalaga) to $20 \%$ (kareish \& double cream) of the street made cheese are free of aerobic bacteria. Our results for kareish cheese are in disagreements with Badawe, (1994) who found that $\mathrm{TABC}$ rage from $10^{7}$ to $10^{9}$ cells/gm.

The public health importance of coliform bacteria is that it is implicated in gastrointestinal illness as gastroenteritis, epidemic diarrhea in children and cases of food poisoning (Quinto and Cepeda, 1997). Coliform testing may be used to determine the effectiveness of cheese milk and to monitor post pasteurization contamination of cheese milk (Chappel and Bigalke, 1987). Data of table (2) showed total Coliform count of some soft Egyptian cheese. From $70 \%$ (thalaga \& douple cream) to $90 \%$ (kareish) of the tested plant made cheese were free of coliform bacteria and from $10 \%$ (kareish \& thalaga) to $20 \%$ (douple cream) of the street made cheese are free of coliform bacteria. From 40\% (kareish) to $75 \%$ (thalaga) of the tested street made cheese have high coliform bacterial count (from $1.5 \times 10^{7} \pm 1.5 \times 10^{7}$ to $7 \times 10^{7} \pm 1 \times 10^{7}$ cells/gm respectively) which is much much higher than allowed by the Standard Egyptian Guidelines (2001). The cheese made in street, farmers' home or in unlicensed factories is not safe for human consumption. Contamination of cheese with coliform gives indication of bad hygienic conditions during production, handling and distribution and the possible presence of enteric pathogens (ICMSF, 1996). Our results are in agreement with Coveney et al. (1994) where they found that the incidence of coliforms and faecal coliforms was higher in soft, semi-soft and semi-hard cheeses than in hard types.

The public health importance of Escherichia coli (E. coli) is that it is implicated in gastrointestinal illness as severe cholera-like syndrome, gastroenteritis, epidemic diarrhea and cases of food poisoning (Quinto and Cepeda, 1997). Data of table (3) showed total Escherichia coli (E. coli) count of some soft Egyptian cheese. The results reveal that Escherichia coli was isolated from 51.5\% (105/200) of soft cheeses tested, but E. coli $\mathrm{O} 157: \mathrm{H} 7$ was not detected. This result is in agreements with Ansay and Kaspar (1997). Forty-seven and half percent $(47.5 \%$, $95 / 200$ ) of the tested cheese, either made in plant $(77 / 100)$ or home or farmers' made (18/100), have zero Escherichia coli (E. coli) count or free from it. The remaining tested cheese samples $(105 / 200,42.5 \%)$ either made in plant $(23 / 100)$ or home or farmers' made (82/100) having total Escherichia coli counts range from $16.47 \pm 3.97$ to $7.2 \times 10^{4} \pm 6.5 \times 10^{4}$ cells/gm which is higher than allowed by the Standard Egyptian Guidelines (2001). It allows Escherichia coli counts up to 10 cells/gm. From $70 \%$ (thalaga \& double cream) to $90 \%$ (kareish) of the tested plant made cheese were free of Escherichia coli bacteria and from $10 \%$ (kareish \& thalaga) to $20 \%$ (double cream) of the street made cheese are free of Escherichia coli bacteria. From $40 \%$ (kareish) to $75 \%$ (thalaga) of the tested street made cheese have high Escherichia coli bacterial count (range from $7.2 \times 10^{4} \pm 6.5 \times 10^{4}$ to $4.8 \times 10^{4} \pm 4.3 \times 10^{4}$ cells/gm respectively) which is much much higher than allowed by the Standard Egyptian Guidelines (2001) which stated that $E$. coli don't exceed 10 cells/gm. It is worthily to note that presence of Escherichia coli in milk and milk products is an indication of direct or indirect feacal contamination. The contamination may be through contaminated hands and /or milk in which the organisms can survive well in improperly heat-treated milk and some 
strains can survive pasteurization (Morgan, 1978). Our result are not in contrast to Quinto and Cepeda (1997) who found toxigenic E. coli of bovine origin and other types of $E$. coli strains in soft cheeses made from raw or pasteurized cow's milk and stated that the toxigenic E. coli can pass to the milk destined to make cheese, and survive and that could make soft cheese to be considered as a possible vehicle of infection. The cheese made in street, farmers' home or in unlicensed factories is not safe for human consumption.

The presence of Staphylococcus aureus in cheese usually indicate contamination of milk from diseased udder or external surface of the dairy animals, or from contaminated, unclean hands of the dairy workers or from their sneezing and coughing of them. Staphylococcus aureus may be the main cause of several food intoxication outbreaks for their production of heat stable enterotoxins (ICMSF, 1996). Data of table (4) reveal total Staphylococcus aureus count of some soft Egyptian cheese. Ninety-eight and half percent (98.5 $\%$, (197/200)) of the tested cheese, either made in plant $(100 / 100)$ or home or farmers' made (3/100), have zero Staphylococcus aureus count or free from it. The remaining tested cheese samples $(1.5 \%,(3 / 200))$ made in plant having total Staphylococcus aureus counts range from 160-185 cells/gm. Staphylococcus aureus was not isolated from any soft cheese made in plant. Our results indicate that Staphylococcus aureus is isolated from 1.5 $\%$ of the tested cheeses, which is lower than recorded by Araujo et al. (2002) who isolated Staphylococcus aureus from 20\% of samples or recorded by De Luca et al. (1997) who they isolated Staphylococcus aureus from $8.3 \%$ of tested soft Brazilian cheese but their count was $2699 \mathrm{CFU} / \mathrm{gm}$. They suggested that the soft cheese might represent a health risk for the consumers and that soft cheese may act as an important vehicle of transmission for well-established pathogens.

Yeasts and moulds counts in cheese are used as an index of the proper sanitation quality. Defects in these unripened soft cheese such as rancidity, softness and colour defects arise mainly from contamination by yeast and mould. Moreover, some species constitutes a public health hazard due to production of mycotoxins (Rippon, 1982). Table (5) show total yeasts and moulds count of some soft Egyptian cheese. Feta and double cream cheeses are free from salmonellas and shigellas. Ninety-seven (97 \%, (194/200)) of the tested cheese, either made in plant $(97 / 100)$ or home or farmers' made $(97 / 100)$, were free from yeasts and moulds. The remaining tested cheese samples $(3 \%,(6 / 200))$ either made in plant $(2 / 100)$ or home or farmers' made $(4 / 100)$ having yeasts and moulds counts range from 110-200 cells/gm which is higher than allowed by the Standard Egyptian Guidelines (2001). It allow yeasts and moulds counts up to 100 cells/gm. Our results agree to somewhat with Coveney et al. (1994) who found that yeasts were found mainly in unpasteurized varieties, especially in the category of soft cheeses and moulds were isolated from non-mouldripened cheeses, as well as from mouldripened varieties.

An imported Irish soft unpasteurized cows' milk cheese was the reason for an outbreak of Salmonella dublin infection that occurred in England and Wales. Salmonella dublin was isolated from these cheeses and these cheese were considered as the vehicle of infection (Maguire et al., 1992). Also an outbreak of Salmonella enterica serotype Typhimurium (S. typhimurium) infection occurred in France due to presence of Salmonella typhimurium in unpasteurized soft cheese, and they considered this soft cheese as an effective vehicle of Salmonella typhimurium transmission (De Valk et al., 2000). Table (6) show total salmonellas and shigellas count of some soft Egyptian cheese. Feta cheeses are free from salmonellas and shigellas. Ninety-seven $(97 \%, 194 / 200)$ of the tested cheese, either made in plant $(97 / 100)$ or home or farmers' made $(97 / 100)$, were free from salmonellas and shigellas. The remaining tested cheese samples $(6 / 200,3 \%)$ either made in plant $(3 / 100)$ or home or farmers' made $(3 / 100)$ having salmonellas and shigellas counts 
range from 5-8 cells/gm. Our results for kareish cheese are in agreements with Badawe, (1996) who detected salmonellas and shigellas in $5 \%$ of the tested samples. Our results for kareish cheese are in disagreements with Abo-Elkhier et al., (1985) and El-kholy et al, (1994) who could not detect salmonellas and shigellas in the tested samples. Our results are in contrast with Coveney et al, (1994), where they didn't detect any salmonellas and shigellas after direct enrichment of Irish farmhouse soft cheeses.

Listeria species especially Listeria monocytogenes has been recognized as bacteria that produce severe illness in animals and humans. Several authors reported the importance of L.isteria monocytogenes as contaminant in foods ready to eat like the soft cheeses (Copes et al., 2000). Listeria monocytogenes, are known to be frequently involved in outbreaks of foodborne listeriosis and sporadic cases of the disease all over the world (Hofer et al., 1998). They noticed higher incidence of Listeria monocytogenes in the homemade Minas Frescal cheeses (a Brazilian soft white cheese, eaten fresh). Considering the importance of the presence or absence of Listeria species in soft cheeses, the 200 samples were analyzed to detect the presence or absence of it. Of the 200 samples, $183(91.5 \%)$ were free of Listeria, the remaining 17 samples $(8.5 \%)$ have listeria count range from 5-20 cells/gm (Table 7). Ten samples $(20 \%)$ of the home or farmers' made Kareish cheese tested having Listeria count range from 1020 cell/gm. Loncarevic (1995) noticed that cheeses made from raw milk were more frequently contaminated with L. monocytogenes than cheeses made from heattreated milk. Our results are in agreements with Loncarevic (1995), Pinto \& Reali (1996), Hofer et al. (1998); and Copes et al, (2000), and disagree with Coveney et al, (1994), where they didn't detect any Listeria species or Listeria monocytogenes after direct enrichment of Irish farmhouse cheeses.

Data of table (8) show the chemical composition of some soft Egyptian cheese. Double cream cheese has the lowest protein content (7.79 \pm 0.78 gm\%) while kareish cheese has the highest protein content $(19.99 \pm 1.32 \mathrm{gm} \%)$, but for fat content the opposite is true, double cream cheese have the highest fat content $(24.56 \pm 1.78 \mathrm{gm} \%)$ while kareish cheese have the lowest fat content $(3.87 \pm 0.97 \mathrm{gm} \%)$. Feta cheese has high ash content while kareish cheese has the highest moisture content with the lowest ash content $(68.97 \pm 1.86 \& 1.81 \pm 0.47 \mathrm{gm} \%$ respectively). Data of table (3) show that the chemical composition of Feta and Thalaga cheese has relatively comparable concentration of protein, fat, ash and moisture. Our results for feta cheese fat \& ash differs from that of food composition tables, FCT (Gordan \& Margaret, 2002, $13.62 \pm 1.31$ vs. $20.2-21.43$; and $7.24 \pm 1.79$ vs. $1.5-3.571 \mathrm{gm} \%$ respectively). Feta' fat is less by $\approx 32.57 \%$ than FCT, while feta'ash is higher by $\approx 382 \%$ than FCT. Also our results agree and disagree to somewhat with Park, 1990, who evaluated concentration profiles of basic nutrients (moisture, fat, protein, and ash) of plain soft caprine cheeses. His mean percentage results of: moisture is (59.8), fat is (22.5), protein is (18.9), and ash is (1.74). Our results for: moisture agree with Park except for kareish cheese; fat strongly disagree except for double cream cheese; protein disagree except for kareish cheese; ash disagree with all types of cheese. Our results are in accordance with the Egyptian Standard guidelines (1991).

The disaccharide lactose is naturally present as a component of foods in milk and dairy products. In the gastrointestinal tract, lactose is hydrolysed by the enzyme beta-galactosidase (lactase) into glucose and galactose, which are absorbed (Sieber et al., 1997; De Vrese et al., 1998; and Szilagyi, 2004). In most people lactase activity decreases at the age of approximately 2 to 6 years of age. After this Lactose in dairy products is mal-digested by up to $70 \%$ to $75 \%$ of the world's population and many people may therefore suffer symptoms reminiscent of irritable bowel syndrome as bloating, flatulence, abdominal pain and diarrhea due to the lactose reaching the large intestine. This phenomenon is called lactose intolerance. It 
is generally recommended that these people abandon the consumption of milk and dairy products. However, most lactose-intolerant people are able to digest small amounts of milk (approximately $200 \mathrm{ml}$ ). They can also consume cheese without or with only low lactose content, only present in $10 \%$ of soft cheese, (Sieber et al., 1997; De Vrese et al., 1998; and Szilagyi, 2004). As a result, most research to date has concentrated on ways of improving lactose tolerance to enhance dairy as a source of nutrition. In view of an exponential growth in the understanding of intestinal microfloral host interactions and the expanding therapeutical potential of probiotics, a reassessment of the role of lactose as a potential prebiotic in lactase nonpersistent subjects is required (Sieber $e t$ al., 1997; De Vrese et al., 1998; and Szilagyi, 2004).

Data of table (8) reveal that lactose content of some soft Egyptian cheese varies widely from $1.50 \pm 0.26 \mathrm{gm} \%$ (double cream cheese) to $3.25 \pm 0.50 \mathrm{gm} \%$ (feta cheese).

Protein content of kareish cheese is significantly higher than the remaining types of cheese $\left(\mathrm{P} \leq 2.0 \times 10^{20}-8.0 \times 10^{31}\right.$, table 11). Protein content of kareish cheese is more than the double content of the double cream cheese. Fat content of kareish cheese is significantly lower than the remaining types of cheese $\left(\mathrm{P} \leqq 3 \times 10^{26}-\right.$ $8.0 \times 10^{35}$, table 11$)$.

Calcium plays an important role in teeth building and many diseases as cardiovascular, osteoporosis and hypertension. Calcium from dairy foods had a large effect on systolic blood pressure. Dairy calcium reduces it in hypertensive not normotensive. Systolic blood pressure is reduced by $2 \mathrm{mmHg}$ for every two cups of milk, $730 \mathrm{mg} \mathrm{Ca}$, consumed per day. No association was observed between nondairy $\mathrm{Ca}$ intake and blood pressure (Ackley et al., 1983; Reed et al., 1985; and Cappuccino et al., 1995). Osteoporosis is a major public health problem (Riggs and Melton, 1995; and Looker et al., 1997). The cause(s) of osteoporosis is multifactorial involving both genetic and environmental factors (Hopper et al., 1998). Accumulating scientific evidence indicates that a sufficient intake of calcium throughout life protects against osteoporosis by achieving genetically programmed peak bone mass reached by 30 years of age or earlier and reducing age-related bone loss (IOM, 1997). The FDA, 1993, has stated that a lifetime of "adequate calcium intake is important for maintenance of bone health and may reduce risk of osteoporosis particularly for individuals at greatest risk". Calcium can be obtained from foods naturally rich in calcium such as dairy foods, from calcium-fortified foods and beverages, from supplements or from a combination of these. Recognition of calcium's many health benefits, along with Egyptian' low calcium intake, has led to interest in how best to meet calcium needs. Foods are the preferred source of calcium. Milk and other dairy foods are the major source of calcium in Egypt. In addition, these foods provide substantial amounts of other essential nutrients. Consequently, intake of dairy foods improves the overall nutritional quality of the diet. Other foods such as some green leafy vegetables, legumes and cereals provide calcium, but generally in lower amounts per serving than do dairy foods. Also, some components such as phytates in cereals and oxalates in spinach reduce the bioavailability of calcium. Calcium-fortified foods and calcium supplements are an option for individuals who cannot meet their calcium needs from foods naturally containing this mineral. However, their intake cannot correct poor dietary patterns of food selection, which underlie Egyptian' low calcium intake (Miller et al., 2001). Recommended Dietary Allowances, RDA, 1989; Dietary Reference Intake, 1997; and IOM, 1997, of calcium intake for children $(1-8 \mathrm{y})$ is $500-800 \mathrm{mg} / \mathrm{day},(9-18 \mathrm{y})$ is 1300 $\mathrm{mg} /$ day; for adults $(19-50 \mathrm{y})$ is 1000 $\mathrm{mg} /$ day and for older (>50 y), it is 1200 $\mathrm{mg} /$ day. It is difficult to obtain such amount without consuming dairy products $(\mathrm{NIH}$, 1994: and AMA, 1997). Data of table (10) show calcium and phosphorus (mg\%) content, and $\mathrm{Ca} / \mathrm{p}$ of some soft Egyptian cheese. Kareish cheese has higher content of calcium and phosphorous (641.1 \pm 49.21 , $431.18 \pm 37.21 \mathrm{mg} \%$ respectively) than the 
remaining types of cheese. Calcium \& phosphorous content of kareish cheese is almost the double content of the double cream cheese. Feta cheese has higher $\mathrm{Ca} / \mathrm{P}$ $(1.65 \pm 0.19)$ while thalaga and double cream has lower $\mathrm{Ca} / \mathrm{P}$ and almost the same $(1.34 \pm 0.13 \& 1.37 \pm 0.20)$.

Calcium \& phosphorous content of kareish cheese is significantly higher than the remaining types of cheese $(\mathrm{P} \leq$ $8.65 \times 10^{8}--5.68 \times 10^{24}$ for $\mathrm{Ca}, 2.76 \times 10^{10}-$ $4.44 \times 10^{19}$ for $\mathrm{P}$, table 11$)$. $\mathrm{Ca} / \mathrm{P}$ of feta cheese is significantly higher than the remaining types of cheese $(\mathrm{P} \leq 0.0049$-$\left.4.6 \times 10^{7}\right)$. No significant difference was found between $\mathrm{Ca} / \mathrm{P}$ of thalaga and double cream cheese.
Table (12) shows \% contribution of $\mathrm{Ca}$ from soft cheese. Each $100 \mathrm{gm}$ of kareish cheese can provide children (1-8 y) with 80.14-128.22\% of their $\mathrm{Ca}$ needs while for adults the $\%$ differ with age. It provides them from $49.32 \%(9-18$ y) to $64.11 \%(19-50$ y). Thalaga and double cream is the least provider compared with kareish cheese, yet they provide a considerable amounts $(24.48-36.73 \%$ of adults needs and 39.78-73.45\% of children needs). Feta cheese provide children from $67.69-108.31 \%$ of their needs while it provide adults from $41.66-54.16 \%$ of their needs.

Table (1): Total Aerobic Bacterial Count (TABC) of Some Soft Egyptian Cheese

\begin{tabular}{|c|c|c|c|c|c|c|c|c|c|c|c|c|c|c|c|c|c|}
\hline & & & \multirow[b]{3}{*}{ no } & \multicolumn{14}{|c|}{ Cells/gm } \\
\hline & & & & & & & & $\leq 10^{2}$ & & \multicolumn{4}{|c|}{$>10^{2}-\leq 3 \times 10^{3}$} & \multicolumn{4}{|c|}{$>3 \times 10^{3}$} \\
\hline & & & & $\begin{array}{l}\text { no } \\
\mathrm{S}\end{array}$ & $\begin{array}{l}\% \\
\mathrm{~S} \\
\end{array}$ & no & $\begin{array}{l}\% \\
\mathrm{~S} \\
\end{array}$ & Mean & Range & no & $\begin{array}{l}\% \\
\mathrm{~S} \\
\end{array}$ & Mean & Range & no & $\begin{array}{l}\% \\
\mathrm{~S}\end{array}$ & Mean & Range \\
\hline \multirow[b]{2}{*}{1} & \multirow{2}{*}{ Kareish } & $\mathrm{a}$ & 20 & 18 & 90 & 0 & 0 & & & 2 & 10 & $\begin{array}{c}300 \\
\pm \\
141.42\end{array}$ & $\begin{array}{c}200 \\
- \\
400\end{array}$ & 0 & 0 & & \\
\hline & & $\mathrm{b}$ & 50 & 10 & 20 & 15 & 30 & $\begin{array}{c}70.87 \\
\pm \\
15.46 \\
\end{array}$ & $45-95$ & 5 & 10 & $\begin{array}{c}1310 \\
\pm \\
1019.4\end{array}$ & $\begin{array}{c}350 \\
- \\
2750\end{array}$ & 20 & 40 & $\begin{array}{c}1.1 \times 10^{5} \\
\pm \\
1.3 \times 10^{5}\end{array}$ & $\begin{array}{c}7500 \\
- \\
5 \times 10^{5}\end{array}$ \\
\hline 2 & \multicolumn{2}{|l|}{ Feta } & 30 & 27 & 90 & 3 & 10 & $\begin{array}{c}45.0 \\
\pm \\
15.0\end{array}$ & $30-60$ & 0 & 0 & & & 0 & 0 & & \\
\hline \multirow[t]{2}{*}{3} & \multirow[t]{2}{*}{ Thalaga } & $\mathrm{a}$ & 20 & 12 & 60 & 6 & 30 & $\begin{array}{c}58.33 \\
\pm \\
16.93 \\
\end{array}$ & $35-80$ & 2 & 10 & $\begin{array}{c}635 \\
\pm \\
360.62\end{array}$ & $\begin{array}{c}380 \\
- \\
890\end{array}$ & 0 & 0 & & \\
\hline & & $\mathrm{b}$ & 20 & 1 & 5 & 2 & 10 & $\begin{array}{c}92.5 \\
\pm \\
3.54 \\
\end{array}$ & $90-95$ & 4 & 10 & $\begin{array}{c}2252.5 \\
\pm \\
418.36 \\
\end{array}$ & $\begin{array}{c}1800 \\
- \\
2700 \\
\end{array}$ & 13 & 65 & $\begin{array}{c}1.2 \times 10^{5} \\
\pm \\
1.6 \times 10^{5}\end{array}$ & $\begin{array}{c}4800 \\
- \\
4.9 \times 10^{5}\end{array}$ \\
\hline \multirow{3}{*}{4} & \multirow{2}{*}{$\begin{array}{l}\text { Double } \\
\text { Cream }\end{array}$} & $\mathrm{a}$ & 30 & 24 & 80 & 3 & 10 & $\begin{array}{c}42.33 \\
\pm \\
7.51 \\
\end{array}$ & $35-50$ & 3 & 10 & $\begin{array}{c}765.67 \\
\pm \\
318.8 \\
\end{array}$ & $\begin{array}{c}470 \\
- \\
1100 \\
\end{array}$ & 0 & 0 & & \\
\hline & & $\mathrm{b}$ & 30 & 6 & 20 & 3 & 10 & $\begin{array}{c}83.67 \\
\pm \\
12.66 \\
\end{array}$ & $70-95$ & 0 & 0 & & & 21 & 70 & $\begin{array}{c}1.4 \times 10^{5} \\
\pm \\
1.7 \times 10^{5}\end{array}$ & $\begin{array}{c}8000 \\
- \\
6.7 \times 10^{5}\end{array}$ \\
\hline & & & 200 & 98 & 49 & 32 & 16 & & & 16 & 8 & & & 54 & 27 & & \\
\hline
\end{tabular}


Chemical, Nutritional and Microbiological Evaluation.......

Table (2): Total Colifrm Count of Some Soft Egyptian Cheese

\begin{tabular}{|c|c|c|c|c|c|c|c|c|c|c|c|c|c|c|c|c|c|}
\hline & & & & \multicolumn{14}{|c|}{ Cells/gm } \\
\hline & & & \multirow[b]{2}{*}{$\underline{\mathrm{no}}$} & \multicolumn{2}{|c|}{0.0} & \multicolumn{4}{|c|}{$\leq 10^{2}$} & \multicolumn{4}{|c|}{$>10^{2}-\leq 3 \times 10^{3}$} & \multicolumn{4}{|c|}{$>3 \times 10^{3}$} \\
\hline & & & & no- & $\begin{array}{l}\% \\
\mathrm{~S}\end{array}$ & $\underline{\mathrm{no}}$ & $\begin{array}{l}\% \\
\mathrm{~S}\end{array}$ & Mean & Range & $\underline{\mathrm{no}}$ & $\begin{array}{l}\% \\
\mathrm{~S}\end{array}$ & Mean & $\begin{array}{c}\text { Rang } \\
\text { e }\end{array}$ & no & $\begin{array}{l}\% \\
\mathrm{~S}\end{array}$ & Mean & Range \\
\hline \multirow{2}{*}{1} & \multirow{2}{*}{ Kareish } & $\mathrm{a}$ & 20 & 18 & 90 & 2 & 10 & $\begin{array}{c}42.5 \\
\pm \\
3.54\end{array}$ & $40-45$ & 0 & 0 & & & 0 & 0 & & \\
\hline & & $\mathrm{b}$ & 50 & 10 & 20 & 10 & 20 & $\begin{array}{c}70.5 \\
\pm \\
14.38\end{array}$ & $50-95$ & 10 & 20 & $\begin{array}{c}1525 \\
\pm \\
808.68 \\
\end{array}$ & $\begin{array}{c}300 \\
- \\
2780\end{array}$ & 20 & 40 & $\begin{array}{c}1.5 \times 10^{7} \\
\pm \\
1.5 \times 10^{7}\end{array}$ & $\begin{array}{c}3700 \\
- \\
7 \times 10^{7}\end{array}$ \\
\hline 2 & \multicolumn{2}{|l|}{ Feta } & 30 & 24 & 80 & 6 & 20 & $\begin{array}{c}48.0 \\
\pm \\
14.83\end{array}$ & $40-70$ & 0 & 0 & & & 0 & 0 & & \\
\hline \multirow{2}{*}{3} & \multirow{2}{*}{ Thalaga } & $\mathrm{a}$ & 20 & 14 & 70 & 4 & 20 & $\begin{array}{c}57.5 \\
\pm \\
13.23\end{array}$ & $45-75$ & 2 & 10 & $\begin{array}{c}500 \\
\pm \\
282.8\end{array}$ & $\begin{array}{c}300 \\
- \\
700\end{array}$ & 0 & 0 & & \\
\hline & & $\mathrm{b}$ & 20 & 2 & 10 & 1 & 5 & 95 & & 2 & 10 & $\begin{array}{c}2250 \\
\pm \\
353.6 \\
\end{array}$ & $\begin{array}{c}2000 \\
- \\
2500 \\
\end{array}$ & 15 & 75 & $\begin{array}{c}7 \times 10^{7} \\
\pm \\
1 \times 10^{7} \\
\end{array}$ & $\begin{array}{c}5000 \\
- \\
4 \times 10^{7} \\
\end{array}$ \\
\hline \multirow{3}{*}{4} & \multirow{2}{*}{$\begin{array}{l}\text { Douple } \\
\text { Cream }\end{array}$} & $\mathrm{a}$ & 30 & 21 & 70 & 3 & 10 & $\begin{array}{c}38.33 \\
\pm \\
7.64\end{array}$ & $30-45$ & 3 & 10 & $\begin{array}{c}733.3 \\
\pm \\
251.7\end{array}$ & $\begin{array}{c}500 \\
- \\
1000\end{array}$ & 3 & 10 & $\begin{array}{c}3.9 \times 10^{7} \\
\pm \\
5.2 \times 10^{7}\end{array}$ & $\begin{array}{c}7800 \\
- \\
9.8 \times 10^{7}\end{array}$ \\
\hline & & $\mathrm{b}$ & 30 & 6 & 20 & 3 & 10 & $\begin{array}{c}83.33 \\
\pm \\
12.85 \\
\end{array}$ & $70-95$ & 3 & 10 & $\begin{array}{c}2466.7 \\
\pm \\
450.9 \\
\end{array}$ & $\begin{array}{c}2000 \\
- \\
2900 \\
\end{array}$ & 18 & 60 & $\begin{array}{c}1 \mathrm{X} 10^{7} \\
\pm \\
2 \mathrm{X} 10^{7}\end{array}$ & $\begin{array}{c}4800 \\
- \\
7 \times 10^{7} \\
\end{array}$ \\
\hline & & & 200 & 95 & $\begin{array}{l}47 \\
.5 \\
\end{array}$ & 29 & $\begin{array}{l}14 \\
.5 \\
\end{array}$ & & & 20 & 10 & & & 56 & 28 & & \\
\hline
\end{tabular}

Table (3): Total Escherichia coli (E. coli) Count of Some Soft Egyptian Cheese

\begin{tabular}{|c|c|c|c|c|c|c|c|c|c|c|c|c|c|c|c|c|c|}
\hline & & & \multirow[b]{3}{*}{$\begin{array}{l}\text { no } \\
\mathrm{S}\end{array}$} & \multicolumn{14}{|c|}{ Cells/gm } \\
\hline & & & & \multicolumn{2}{|l|}{0.0} & \multicolumn{4}{|c|}{$\leq 10^{2}$} & \multicolumn{4}{|c|}{$>10^{2}-\leq 3 \times 10^{3}$} & \multicolumn{4}{|c|}{$>3 \times 10^{3}$} \\
\hline & & & & no & $\begin{array}{l}\% \\
\text { S }\end{array}$ & no & $\begin{array}{l}\% \\
\text { S }\end{array}$ & Mean & Range & no & $\begin{array}{l}\% \\
\text { S }\end{array}$ & Mean & $\begin{array}{l}\text { Rang } \\
\mathrm{e}\end{array}$ & no & $\begin{array}{l}\% \\
S\end{array}$ & Mean & Range \\
\hline \multirow{2}{*}{1} & \multirow{2}{*}{ Kareish } & $\mathrm{a}$ & 20 & 18 & 90 & 2 & 10 & $\begin{array}{l}25.0 \\
\pm \\
7.07\end{array}$ & $20-30$ & 0 & 0 & & & 0 & 0 & & \\
\hline & & $\mathrm{b}$ & 50 & 10 & 20 & 10 & 20 & $\begin{array}{l}46.6 \\
\pm \\
9.87 \\
\end{array}$ & $30-60$ & 10 & 20 & $\begin{array}{l}680 \\
\pm \\
261.25 \\
\end{array}$ & $\begin{array}{l}350 \\
- \\
1000 \\
\end{array}$ & 20 & 40 & $\begin{array}{l}7.2 \times 10^{4} \\
\pm \\
6.5 \times 10^{4}\end{array}$ & $\begin{array}{l}6500 \\
- \\
2.2 \times 10^{5} \\
\end{array}$ \\
\hline 2 & Feta & & 30 & 24 & 80 & 6 & 20 & $\begin{array}{l}16.17 \\
\pm \\
3.97\end{array}$ & $10-21$ & 0 & 0 & 0 & & 0 & 0 & & \\
\hline \multirow{2}{*}{3} & \multirow{2}{*}{ Thalaga } & $\mathrm{a}$ & 20 & 14 & 70 & 4 & 20 & $\begin{array}{l}37.0 \\
\pm \\
6.78 \\
\end{array}$ & $30-45$ & 2 & 10 & $\begin{array}{l}300 \\
\pm \\
141.42 \\
\end{array}$ & $\begin{array}{l}200 \\
- \\
400 \\
\end{array}$ & 0 & 0 & & \\
\hline & & $\mathrm{b}$ & 20 & 2 & 10 & 1 & 5 & 50 & & 2 & 10 & $\begin{array}{l}1200 \\
\pm \\
424.26\end{array}$ & $\begin{array}{l}900 \\
- \\
1500\end{array}$ & 15 & 75 & $\begin{array}{l}4.8 \times 10^{4} \\
\pm \\
4.3 \times 10^{4}\end{array}$ & $\begin{array}{l}5400 \\
- \\
1.7 \times 10^{5}\end{array}$ \\
\hline \multirow[b]{2}{*}{4} & \multirow{2}{*}{$\begin{array}{l}\text { Douple } \\
\text { Cream }\end{array}$} & $\mathrm{a}$ & 30 & 21 & 70 & 3 & 10 & $\begin{array}{l}38.33 \\
\pm \\
7.64\end{array}$ & $30-45$ & 3 & 10 & $\begin{array}{l}570.0 \\
\pm \\
141.07\end{array}$ & $\begin{array}{l}420 \\
- \\
700\end{array}$ & 3 & 10 & $\begin{array}{l}5.5 \times 10^{4} \\
\pm \\
4.1 \times 10^{4}\end{array}$ & $\begin{array}{l}9500 \\
- \\
9.1 \times 10^{4}\end{array}$ \\
\hline & & $\mathrm{b}$ & 30 & 6 & 20 & 3 & 10 & $\begin{array}{l}56.67 \\
\pm \\
15.28\end{array}$ & $40-70$ & 3 & 10 & $\begin{array}{l}1587 \\
\pm \\
454.5\end{array}$ & $\begin{array}{l}1100 \\
- \\
2000\end{array}$ & 18 & 60 & $\begin{array}{l}6.6 \times 10^{4} \\
\pm \\
6.4 \times 10^{4}\end{array}$ & $\begin{array}{l}6500 \\
- \\
2.2 \times 10^{5}\end{array}$ \\
\hline & & & 200 & 95 & $\begin{array}{l}47 \\
.5 \\
\end{array}$ & 29 & $\begin{array}{l}14 \\
.5 \\
\end{array}$ & & & 20 & 10 & & & 56 & 28 & & \\
\hline
\end{tabular}


Table (4): Total Staphylococcus aureus Count of Some Soft Egyptian Cheese

\begin{tabular}{|c|c|c|c|c|c|c|c|c|c|}
\hline & & & & \multicolumn{6}{|c|}{ Cells/gm } \\
\hline & & & \multirow[b]{2}{*}{ no } & \multicolumn{2}{|c|}{0.0} & \multicolumn{4}{|c|}{$>10^{2}-\leq 3 \times 10^{3}$} \\
\hline & & & & noo & $\begin{array}{l}\% \\
\text { S }\end{array}$ & $\underline{\text { no }}$ & $\begin{array}{l}\% \\
\mathbf{S}\end{array}$ & Mean & Range \\
\hline \multirow{2}{*}{1} & \multirow{2}{*}{ Kareish } & $\mathbf{a}$ & 20 & 20 & 100 & $\mathbf{0}$ & $\mathbf{0}$ & & \\
\hline & & b & 50 & 49 & 98 & 1 & 2 & 185 & \\
\hline 2 & \multicolumn{2}{|l|}{ Feta } & 30 & 30 & 100 & $\mathbf{0}$ & $\mathbf{0}$ & & \\
\hline \multirow{2}{*}{3} & \multirow{2}{*}{ Thalaga } & $\mathbf{a}$ & 20 & 20 & 100 & $\mathbf{0}$ & 0 & & \\
\hline & & $\mathbf{b}$ & 20 & 19 & 95 & 1 & 5 & $175 \pm 35.36$ & $110-150$ \\
\hline \multirow{3}{*}{4} & \multirow{2}{*}{$\begin{array}{l}\text { Douple } \\
\text { Cream }\end{array}$} & $\mathbf{a}$ & 30 & 30 & 100 & $\mathbf{0}$ & $\mathbf{0}$ & & \\
\hline & & b & 30 & 29 & 96.7 & 1 & 3.3 & 160 & \\
\hline & & & 200 & 197 & 98.5 & 3 & 1.5 & & \\
\hline
\end{tabular}

Table (5): Total yeasts and moulds Count of Some Soft Egyptian Cheese

\begin{tabular}{|c|c|c|c|c|c|c|c|c|c|}
\hline & & & & \multicolumn{6}{|c|}{ "Cells/gm } \\
\hline & & & \multirow[b]{2}{*}{ no } & \multicolumn{2}{|c|}{0.0} & \multicolumn{4}{|c|}{$>10^{2}-\leq 3 \times 10^{3}$} \\
\hline & & & & no & $\begin{array}{l}\% \\
\mathrm{~S}\end{array}$ & no & $\begin{array}{l}\% \\
\text { S }\end{array}$ & Mean & Range \\
\hline \multirow{2}{*}{1} & \multirow{2}{*}{ Kareish } & $\mathbf{a}$ & 20 & 19 & 95 & 1 & 5 & 110 & \\
\hline & & b & 50 & 49 & 98 & 1 & 2 & 175 & \\
\hline 2 & \multicolumn{2}{|l|}{ Feta } & 30 & 30 & 100 & $\mathbf{0}$ & $\mathbf{0}$ & & \\
\hline \multirow{2}{*}{3} & \multirow{2}{*}{ Thalaga } & $\mathbf{a}$ & 20 & 19 & 95 & 1 & 5 & 110 & \\
\hline & & b & 20 & 18 & 90 & 2 & 10 & $175 \pm 35.36$ & 150-200 \\
\hline \multirow{3}{*}{4} & \multirow{2}{*}{$\begin{array}{l}\text { Douple } \\
\text { Cream } \\
\end{array}$} & $\mathbf{a}$ & 30 & 30 & 100 & $\mathbf{0}$ & $\mathbf{0}$ & & \\
\hline & & $\mathbf{b}$ & 30 & 29 & 96.7 & 1 & 3.3 & 160 & \\
\hline & & & 200 & 194 & 97 & 6 & 3 & & \\
\hline
\end{tabular}

A: Plant

b: Home or Farmers' made

no S: Number of Samples

Table (6): Total Salmonellas and Shigellas Count of Some Soft Egyptian Cheese

\begin{tabular}{|c|c|c|c|c|c|c|c|c|c|}
\hline & & & & \multicolumn{6}{|c|}{ Cells/gm } \\
\hline & & & & \multicolumn{2}{|c|}{0.0} & \multicolumn{4}{|c|}{$\leq 10^{2}$} \\
\hline & & & $\frac{\text { no }}{\mathrm{S}}$ & no & $\begin{array}{l}\% \\
\text { S }\end{array}$ & no & $\begin{array}{l}\% \\
\mathrm{~S}\end{array}$ & Mean & Range \\
\hline \multirow{2}{*}{1} & \multirow{2}{*}{ Kareish } & $\mathbf{a}$ & 20 & 19 & 95 & 1 & 5 & 5 & \\
\hline & & $\mathbf{b}$ & 50 & 49 & 98 & 1 & 2 & 8 & \\
\hline 2 & \multicolumn{2}{|l|}{ Feta } & 30 & 30 & 100 & $\mathbf{0}$ & $\mathbf{0}$ & & \\
\hline \multirow{2}{*}{3} & \multirow{2}{*}{ Thalaga } & $\mathbf{a}$ & 20 & 19 & 95 & 1 & 5 & 5 & \\
\hline & & $\mathbf{b}$ & 20 & 19 & 95 & 1 & 5 & 8 & \\
\hline \multirow{3}{*}{4} & \multirow{2}{*}{ Douple Cream } & $\mathbf{a}$ & 30 & 29 & 96.7 & 1 & 3.3 & 5 & \\
\hline & & $\mathbf{b}$ & 30 & 29 & 96.7 & 1 & 3.3 & 7 & \\
\hline & & & 200 & 194 & 97 & 6 & 3 & & \\
\hline
\end{tabular}


Table (7): Total Listeria species Count of Some Soft Egyptian Cheese

\begin{tabular}{|c|c|c|c|c|c|c|c|c|c|}
\hline & & & & \multicolumn{6}{|c|}{ Cells/gm } \\
\hline & & & \multirow[b]{2}{*}{$\underset{\mathbf{S}}{\text { No }}$} & \multicolumn{2}{|c|}{0.0} & \multicolumn{4}{|c|}{$\leq 10^{2}$} \\
\hline & & & & $\underline{\text { no }}$ & $\begin{array}{l}\% \\
\mathrm{~S}\end{array}$ & no & $\begin{array}{l}\% \\
\mathrm{~S} \\
\end{array}$ & Mean & Range \\
\hline \multirow{2}{*}{1} & \multirow{2}{*}{ Kareish } & $\mathbf{a}$ & 20 & 19 & 95 & 1 & 5 & 10 & \\
\hline & & b & 50 & 40 & 80 & 10 & 20 & $13.8 \pm 3.12$ & $10-20$ \\
\hline 2 & \multicolumn{2}{|l|}{ Feta } & 30 & 30 & 100 & $\mathbf{0}$ & $\mathbf{0}$ & & \\
\hline \multirow{2}{*}{3} & \multirow{2}{*}{ Thalaga } & $\mathbf{a}$ & 20 & 19 & 95 & 1 & 5 & 10 & \\
\hline & & b & 20 & 18 & 90 & 2 & 10 & $7.5 \pm 3.45$ & $5-10$ \\
\hline \multirow{3}{*}{4} & \multirow{2}{*}{ Douple Cream } & $\mathbf{a}$ & 30 & 29 & 96.7 & 1 & 3.3 & 10 & \\
\hline & & b & 30 & 28 & 93.3 & 2 & 6.7 & $10.0 \pm 7.07$ & $5-15$ \\
\hline & & & 200 & 183 & 91.5 & 17 & 8.5 & & \\
\hline
\end{tabular}

a: Plant

b: Home or Farmers' made

no S: Number of Samples

Table (8): Chemical Composition (gm/100 gm) of Some Soft Egyptian Cheese

\begin{tabular}{|c|c|c|c|c|c|c|c|c|c|}
\hline & & & & Protein & Fat & Ash & Moisture & $\begin{array}{c}\text { Carbo- } \\
\text { hydrate }\end{array}$ & Lactose \\
\hline 1 & \multirow{2}{*}{ Kareish } & \multirow{2}{*}{70} & $\mathbf{M}$ & $19.99 \pm 1.32$ & $3.87 \pm 0.97$ & $1.81 \pm 0.47$ & $68.97 \pm 1.86$ & $5.37 \pm 0.44$ & $2.00 \pm 0.33$ \\
\hline 1 & & & $\mathbf{R}$ & $17.70-22.5$ & $2.20-5.78$ & $1.00-2.80$ & 64.78-71.70 & $4.55-6.03$ & $1.56-2.65$ \\
\hline \multirow{3}{*}{2} & \multirow{3}{*}{ Feta } & \multirow{3}{*}{30} & $\mathbf{M}$ & $11.12 \pm 0.81$ & $13.62 \pm 1.31$ & $6.42 \pm 0.65$ & $61.60 \pm 2.64$ & $7.24 \pm 1.79$ & $3.25 \pm 0.50$ \\
\hline & & & $\mathbf{R}$ & $9.90-12.70$ & $11.90-15.50$ & $5.20-7.32$ & $57.0-64.8$ & $4.40-11.30$ & $2.10-4.10$ \\
\hline & & & $\mathbf{F}$ & $14.27-15.6$ & $20.2-21.43$ & 5.71-6.2 & $55.0-56.5$ & $1.5-3.571$ & \\
\hline \multirow[b]{2}{*}{3} & \multirow{2}{*}{ Thalaga } & \multirow{2}{*}{40} & M & $12.81 \pm 1.16$ & $14.96 \pm 1.23$ & $5.05 \pm 0.63$ & $62.25 \pm 1.82$ & $4.93 \pm 0.58$ & $1.79 \pm 0.21$ \\
\hline & & & $\mathbf{R}$ & $10.80-15.6$ & $11.90-16.95$ & 3.95-6.25 & $58.17-66.02$ & 3.85-5.89 & $1.56-2.12$ \\
\hline \multirow{2}{*}{4} & \multirow{2}{*}{$\begin{array}{l}\text { Double } \\
\text { Cream }\end{array}$} & \multirow{2}{*}{60} & $\mathbf{M}$ & $7.79 \pm 0.78$ & $24.56 \pm 1.78$ & $3.91 \pm 0.49$ & $59.64 \pm 1.80$ & $4.10 \pm 0.61$ & $1.50 \pm 0.26$ \\
\hline & & & $\mathbf{R}$ & $6.69-9.30$ & $21.9-28.54$ & $3.0-4.90$ & $56.65-62.01$ & $3.0-5.20$ & $1.05-1.90$ \\
\hline
\end{tabular}

M: (Mean \pm SD);

R: Range;

F: Gordan \& Margaret (2002)

Table (9): $P$ values for the comparison between double cream, feta, kareish and thalaga soft cheese

\begin{tabular}{||c|c|c|c|c|c|c||}
\hline & Protein & Fat & Ash & Moisture & Carbohydrate & Lactose \\
\hline D vs. F & $8.0 \times 10^{16}$ & $2.0 \times 10^{23}$ & $2.2 \times 10^{16}$ & $4.93 \times 10^{16}$ & $1.02 \times 10^{15}$ & $1.68 \times 10^{16}$ \\
\hline D vs. K & $8.0 \times 10^{31}$ & $8.0 \times 10^{35}$ & $1.7 \times 10^{16}$ & $9.37 \times 10^{11}$ & $4.34 \times 10^{9}$ & $4.12 \times 10^{6}$ \\
\hline D vs. TH & $2.0 \times 10^{5}$ & $1.0 \times 10^{21}$ & $1.8 \times 10^{7}$ & $3.52 \times 10^{16}$ & $7.74 \times 10^{5}$ & 0.0004 \\
\hline TH vs. K & $2.0 \times 10^{20}$ & $6.0 \times 10^{29}$ & $1.5 \times 10^{20}$ & $5.36 \times 10^{14}$ & 0.011 & 0.019 \\
\hline TH vs. F & $5.0 \times 10^{6}$ & 0.0018 & $5.2 \times 10^{8}$ & $\mathrm{NS}$ & $4.62 \times 10^{15}$ & $1.46 \times 10^{14}$ \\
\hline K vs. F & $1.0 \times 10^{25}$ & $3.0 \times 10^{26}$ & $1.2 \times 10^{25}$ & $1.99 \times 10^{12}$ & $9.72 \times 10^{15}$ & $2.3 \times 10^{11}$ \\
\hline
\end{tabular}

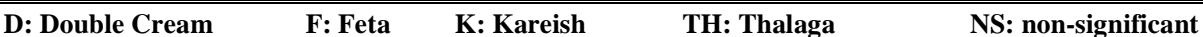


Table (10): Calcium and Phosphorus (mg\%) content, and Ca/p of some soft Egyptian cheese

\begin{tabular}{|c|c|c|c|c|c|c|}
\hline & & & & $\mathrm{Ca}(\mathrm{mg} \%)$ & $P(\mathrm{mg} \%)$ & $\mathrm{Ca} / \mathrm{P}$ \\
\hline \multirow{2}{*}{1} & \multirow{2}{*}{ Kareish } & \multirow{2}{*}{$\mathbf{7 0}$} & $\mathbf{M}$ & $641.1 \pm 49.21$ & $431.18 \pm 37.21$ & $1.49 \pm 0.14$ \\
\hline & & & $\mathbf{R}$ & $565.0-728.0$ & $364.0-497.0$ & 1.24-1.80 \\
\hline \multirow{3}{*}{2} & \multirow{3}{*}{ Feta } & \multirow{3}{*}{30} & M & $541.55 \pm 46.17$ & $330.29 \pm 38.08$ & $1.65 \pm 0.19$ \\
\hline & & & $\mathbf{R}$ & $470.0-612.0$ & $276.0-400.0$ & 1.33-2.07 \\
\hline & & & $\mathbf{F}$ & 500 & 342.86 & 1.46 \\
\hline \multirow{2}{*}{3} & \multirow{2}{*}{ Thalaga } & \multirow{2}{*}{40} & $\mathbf{M}$ & $367.25 \pm 37.34$ & $275.45 \pm 26.23$ & $1.34 \pm 0.13$ \\
\hline & & & $\mathbf{R}$ & $307.0-441.0$ & 235.0-314.0 & $1.14-1.65$ \\
\hline \multirow{2}{*}{4} & \multirow{2}{*}{ Double Cream } & \multirow{2}{*}{60} & $\mathbf{M}$ & $318.2 \pm 38.55$ & $235.6 \pm 36.92$ & $1.37 \pm 0.20$ \\
\hline & & & $\mathbf{R}$ & $257.0-391.0$ & $179.0-286.0$ & $1.08-1.83$ \\
\hline
\end{tabular}

M: (Mean \pm SD); $\quad$ R: Range;

F: Gordan \& Margaret (2002)

Table (11): $P$ values for the comparison between double cream, feta, kareish and thalaga soft cheese

\begin{tabular}{|c|c|c|c|}
\hline & $\mathbf{C a}$ & $\mathbf{P}$ & $\mathrm{Ca} / \mathbf{P}$ \\
\hline D vs. F & $5.19 \times 10^{19}$ & $1.2 \times 10^{9}$ & $5.66 \times 10^{5}$ \\
\hline D vs. $K$ & $5.68 \times 10^{24}$ & $4.44 \times 10^{19}$ & 0.034 \\
\hline D vs. TH & 0.0002 & 0.0003 & NS \\
\hline TH vs. K & $1.22 \times 10^{21}$ & $7.93 \times 10^{18}$ & 0.001 \\
\hline TH vs. F & $1.07 \times 10^{15}$ & $5.12 \times 10^{6}$ & $4.6 \times 10^{7}$ \\
\hline K vs. F & $8.65 \times 10^{8}$ & $2.76 \times 10^{10}$ & 0.0049 \\
\hline
\end{tabular}

D: Double Cream

F: Feta

K: Kareish

TH: Thalaga

NS: non-significant

Table (12): \% Contribution of Ca from soft cheese.

\begin{tabular}{|c|c|c|c|c|c|}
\hline & \multirow{3}{*}{$\begin{array}{c}\text { Age } \\
\begin{array}{c}\text { Ca } \\
(\mathrm{mg} / \mathrm{day})\end{array}\end{array}$} & $1-8 y$ & $9-18 y$ & $19-50 \mathrm{y}$ & $>50 y$ \\
\hline & & \multicolumn{4}{|c|}{ Dietary Reference Intake, 1997} \\
\hline & & $500-800$ & 1300 & 1000 & 1200 \\
\hline 1 & Kareish & 80.14-128.22 & 49.32 & 64.11 & 53.43 \\
\hline 2 & Feta & 67.69-108.31 & 41.66 & 54.16 & 45.13 \\
\hline 3 & Thalaga & 45.91-73.45 & 28.25 & 36.73 & 30.6 \\
\hline 4 & Double cream & 39.78-63.64 & 24.48 & 31.82 & 26.52 \\
\hline
\end{tabular}

\section{Recommendation}

Since plants construction affect microbial contamination and overall wholesomeness of the products so it is important that clean air and water are available and the used equipments and the contact surfaces are always clean and do not react the products and keep proper and effective sanitation. Each processing facility, equipments, raw materials and products should go daily through microbial analysis. Also the workers in this field should be carefully chosen with a good care of them and ensure that they apply health rules.
Soft cheeses might represent a health risk for the consumers and considered as a possible vehicle of infection or vehicle of transmission for well-established pathogens so the cheese made in street, farmers' home or in unlicensed factories is not safe for human consumption.

The dairy animals especially the udder must be checked and the infected animals or the herd must be isolated.

More and more of proper inspection must be done on street markets, supermarkets, stores, plants, unlicensed factories and farmers' animal, milk \& dairy products. 
Applying more strict rolles especially for those who gaperdize people health.

Considering the adverse health and economic effects of low calcium intakes, strategies are needed to optimize calcium intake. First step is to understand why consuming foods containing calcium is the best way to meet calcium needs.

\section{References}

1. Ahmed, E. Y., and Carolyn, C., (2003): "Food Microbiology; A laboratory manual". A John Wiley \& sons, Inc. Publications.

2. Abo-Elkhier, F. A., El-Bassiony, T., and Gadel-Rab, H., (1985): "Enterobacteriaceae in some milk products in Sohage city". Assuit Vet. Med. J., 14; 28.

3. Ackley, s., Barrett-Connor, E., and Suarez, L., (1983): "Dairy products, calcium, and blood pressure". Amr. J. Clinic. Nutri., 38: 457.

4. Al_Ashmawy, A. M., El_Gemiey, S. R., Amer, I. H., and Hatab, M. S., (1994): "Bacteriological quality of cheese in Dakahilia governorate". Assuit Vet. Med. J., 31:

5. AMA, American Medical Assocciation, (1997): Council on scientific affairs, intake of dietary calcium to reduce the incidence of osteoporosis". Arch. Farm. Med., 6: 495.

6. Ansay, S. E., and Kaspar, C. W., (1997): "Survey of retail cheeses, dairy processing environments and raw milk for Escherichia coli O157:H7”. Lett. Appl. Microbiol., 25: 131-134.

7. Araujo, V. S., Pagliares, V. A., Queiroz, M. L., and Freitas-Almeida, A. C., (2002): "Occurrence of Staphylococcus and enteropathogens in soft cheese comercialized in the city of Rio de Janeiro, Brazil". J. Appl. Microbiol., 92: 1172-1177.

8. AOAC (1981): "Official method of analysis of the Association of Official Analytical Chemists. Published by the association of official analytical chemists, Inc., Arlington, USA.

9. AOAC (1990): "Official method of analysis of the Association of Official Analytical Chemists. Published by the association of official analytical chemists, Inc., Arlington, USA.

10. Badawi, O. F. H., (1996): "Dairy products as source of some bacterial zoonoses". Ph D Thesis, Faculty of Vet. Med. Cairo University.
11. Cappuccino, F. P., Elliott, P., Allender, P. S., Pryer, J., Follman, D. A., and Cutler, J. A., (1995): "Epidemologic association between dietary calcium intake and blood pressure: a meta-analysis of publicshed data". Amr. J. Epidemol., 142: 935.

12. Chappel, R., and Bigalke, D.,( 1987): Dairy Science Field, 170:22.

13. Copes, J., Pellicer, K., Echeverria, H. G., Stanchi, N. O., Martinez, C., and Leardini, N., (2000): "Investigation of Listeria monocytogenes in soft cheeses". Rev. Argent. Microbiol., 32: 49-52.

14. Coveney, H. M., Fitzgerald, G. F., and Daly, C., (1994): "A study of the microbiological status of Irish farmhouse cheeses with emphasis on selected pathogenic and spoilage micro-organisms". J. Appl. Bacteriol., 77: 621-630.

15. Da Silva, M. C., Hofer, E., and Tibana, A., (1998): "Incidence of Listeria monocytogenes in cheese produced in Rio de Janeiro, Brazil". J. Food Prot., 61: 354-356.

16. De Luca, G., Zanetti, F., and Stampi, S., (1997): "Staphylococcus aureus in dairy products in the Bologna area". Int. J. Food Microbiol., 35: 267-270.

17. De Valk, H., Delarocque-Astagneau, E., Colomb, G., Ple, S., Godard, E., Vaillant, V., Haeghebaert, S., Bouvet, P. H., Grimont, F., Grimont, P., Desenclos, J. C., (2000): "A community--wide outbreak of Salmonella enterica serotype Typhimurium infection associated with eating a raw milk soft cheese in France". Epidemiol. Infect., 124: 1-7.

18. De Vrese, M., Sieber, R., and Stransky, M., (1998): "Lactose in human nutrition". Schweiz. Med. Wochenschr., 128: 13931400.

19. Dietary Reference Intake, (1997): "Calcium intake recommendations". National dairy council internal communication.

20. Egyption Standard Gurdeliness.(2001) for Softegyptian cheese .

21. El-kholy, A. M., Hafez,R. S., and Mahmoud, M. D., (1994): "Occurrence of some food-poisoning bacteria in Egyptian soft cheese". Food Hygiene Dep. Fac. Vet. Med. Beni-Seuf. Cairo, University.

22. FDA, Food and Drug Administration, (1993): "U. S. Department of health and human services, Food and Drug Administration, food labeling: health claims; calcium and osteoporosis, Fed. Register, 58: 2665.

23. Food composition tables for Egypt, (1998), Nutrition Institute, $2 \stackrel{\text { nd }}{ }$ Ed 
24. Gordan, M. W., and Margaret, W. K., (2002): "Perspective in Nutrition". $5^{\text {th }}$ Ed. McGraw Hill.

25. Hopper, J. L., Green, R. M., Nowson, C. A., Young, D., Sherwin, A. J., Kaymakci, B., Larkins, R. G., and Wark, J. D., (1998):"Genetic, common environment, and individual specific components of variance for bone density in 10- to 26- year old females: a twin study". Amr. J. Epidemol., 147: 17.

26. IOM, Institute of Medicine, (1997): "Dietary reference intakes for calcium, Phosphorous, Magnesium, Vitamin D, and Fluoride, Standing committee on the scientific evaluation of dietary reference intake, Food and nutrition board, National academy press, Washington, D. C.

27. ICMSF, (1996): "International Committee of Microbiological Specification of Food, Microorganism in foods. Microbiological specification of food pathogens, $1 \stackrel{\text { st }}{\mathrm{Ed}}$. Black academic and professional, London, Pages 112-300.

28. James, G. C., and Natalie, S., (2002): "Microbiology; A laboratory manual". Part II. $6^{\text {th }}$ Ed. Benjman Cummings, N. Y.

29. Loncarevic, S., Danielsson-Tham, M. L., and Tham, W., (1995): "Occurrence of Listeria monocytogenes in soft and semisoft cheeses in retail outlets in Sweden". Int. J. Food Microbiol., 26: 245-250.

30. Looker, A. C., Orwoll, E. S., Johnston, C. C., Jr., Lindsay, R. L., Wahner, H. W., Dunn, W. L., Calvo, M. S., Harris, J. B., and Heyse, S. P., (1997): "Prevalence of low femoral bone density in older U. S. adults from NHANES III". J. Bone Miner. Res., 12: 1761.

31. Maguire, H., Cowden, J., Jacob, M., Rowe, B., Roberts, D., Bruce, J., Mitchell, E., (1992): "An outbreak of Salmonella dublin infection in England and Wales associated with a soft unpasteurized cows' milk cheese". Epidemiol. Infect., 109: 389-396.

32. Marriott, G. N., (1999): "Principles of Food sanitation". $4^{\text {th }}$ Ed. USA.

33. Miller, G. D., Jarvis, J. K., and McBean, L. D., (1999): "Handbook of dairy foods and nutrition. $2^{\mathrm{nd}}$ Ed. ndc. CRC press LLC.

34. Miller, G. D., Jarvis, J. K., and McBean, L. D., (2001): "The importance of meeting calcium needs with foods". J. Am. Coll. Nutri., 20(2 Suppl): 168S-185S.

35. Morgan, R. S., Hafez,R. S., and Sheliah, M. A., (1987): "Prevalence of enteropathogenic Escherichia coli in milk and dairy products". Alex. J. Vet. Sci., 3: 2.

36. NIH, National Institute of Health, (1994): U. S. Department of health and human services, Public health service, Consensus Development Conference Statement, Optimal calcium intake, 12: 1.

37. Ottogalli , G., Rondinini, G., and Panto, C., (1985): "Microbial contamination in some soft cheese. What tests and what limits? Latte., 10: 556-562. Dairy Sci. Abs., 89: 667.

38. Park, Y. W., (1990): "Nutrient profiles of commercial goat milk cheeses manufactured in the United States". J. Dairy Sci., 73: 3059-3067.

39. Park, Y. W., (2000): "Comparison of mineral and cholesterol composition of different commercial goat milk products manufactured in USA". Small Rumin. Res., 37: 115-124.

40. Pinto, B., and Reali, D., (1996): "Prevalence of Listeria monocytogenes and other listerias in Italian-made soft cheeses". Zentralbl. Hyg. Umweltmed., 199: 60-68.

41. Quinto, E. J., and Cepeda, A., (1997): "Incidence of toxigenic Escherichia coli in soft cheese made with raw or pasteurized milk". Lett. Appl. Microbiol., 24: 291-295.

42. RDA, Recommended Dietary Allowances, (1989): "Food and nutrition board, subcommittee on the tenth edition of the RDAs, national research council, 10 th Ed., National academy press, Washington, D. C.

43. Reed, D., MacGee, D., Yano, K., and Hankin, J., (1985): "Diet, blood pressure and multicolinearity". Hypertension, 7: 405.

44. Riggs, B. L., and Melton, L. J., III, (1995): "The worldwide problem of osteoporosis: insights afforded by epidemiology bone, 17: 505s.

45. Rippon, J. W., (1982): "Medical mycology. The pathogenic fungi and pathogenic actinomycology". W. B. Saunders. Co., Philadelphia.

46. Sieber, R., Stransky, M., and De Vrese, M., (1997): "Lactose intolerance and consumption of milk and milk products". Z. Ernahrungswiss., 36: 375-93.

47. Szilagyi, A., (2004): "Redefining lactose as a conditional prebiotic". Can. J. Gastroenterol., 18: 163-167

48. UNEP, (1992): "The contamination of foods, UNEP/GEMS environmental library. No. 5. UNEP, Nairobi. 


\section{تقييم كيميائي، غذائي و ميكروبيولوجي لبغض أنواع الجبن المصري الطري}

1*غادة،ز. ع. سليمان، 2** علياء م. هاثم، 3**شها الس.؛ 4*مجدي، ن. عزمي، 5*محمد، ف. ف. صديق

1 قسم الكيمباء الحيوية، 2 قسم صحة طعام ، 3 قسم تغذية ، 4 قسم علوم بيئية ، 5 قسم ميكروبيولجي

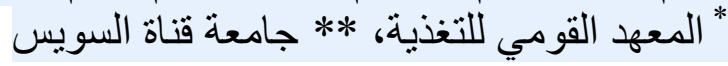

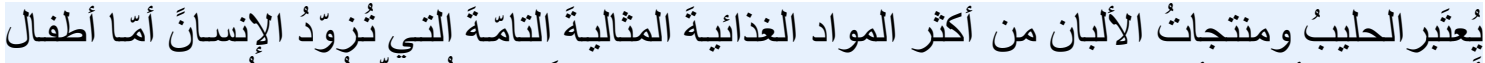

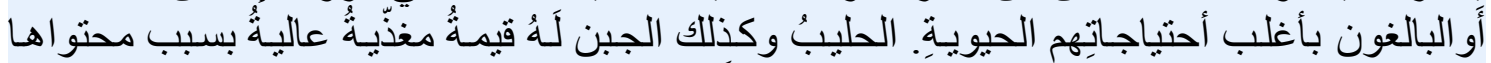

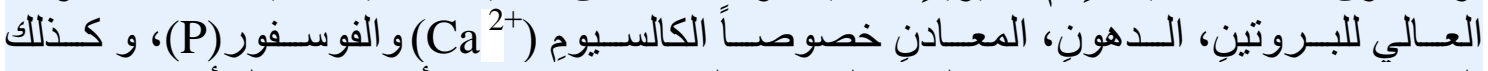

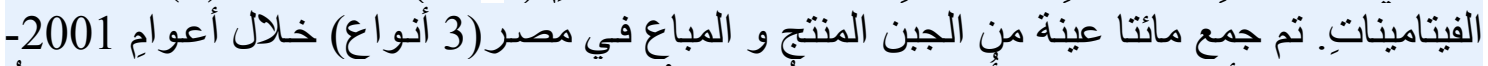

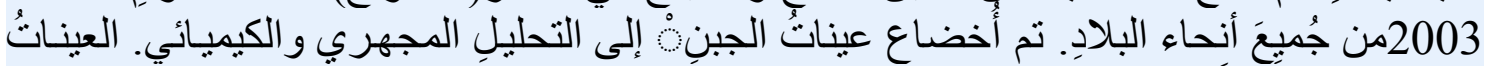

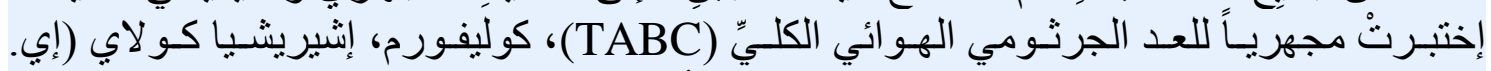

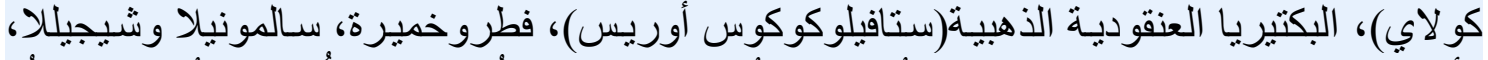

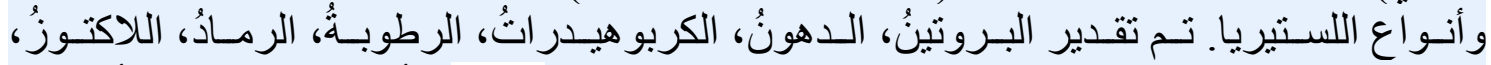

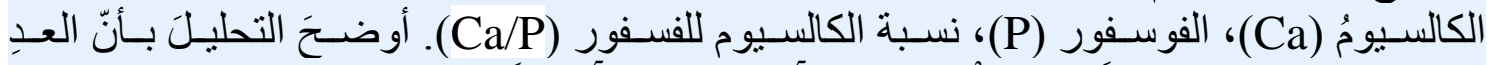

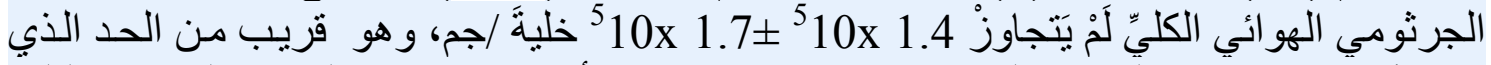

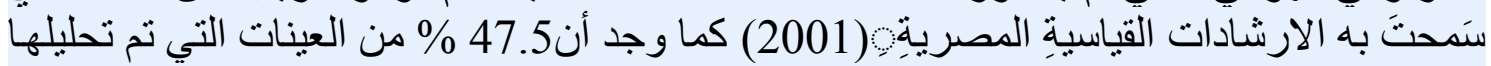

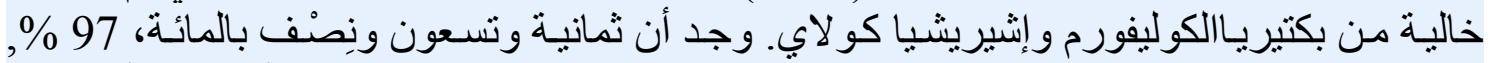

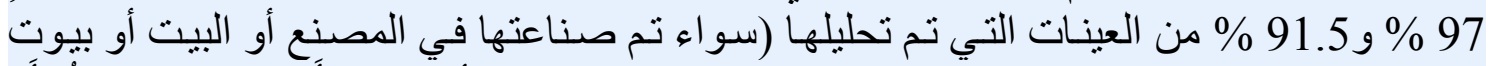

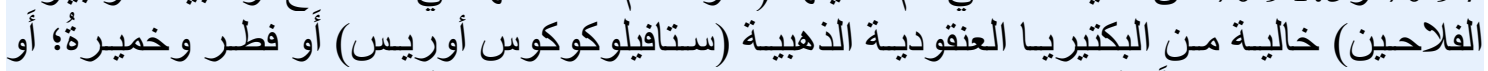

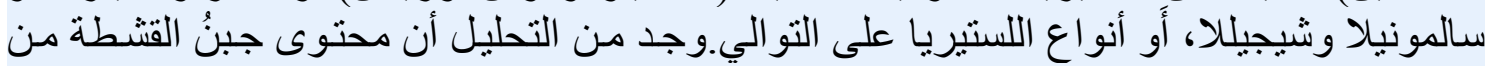

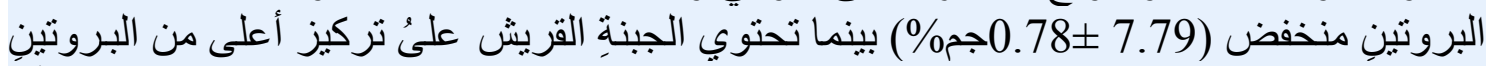

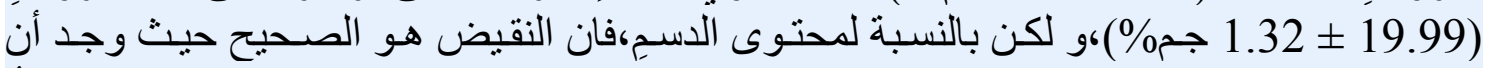

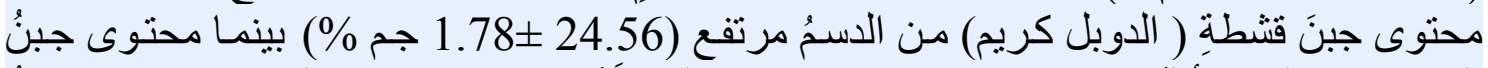

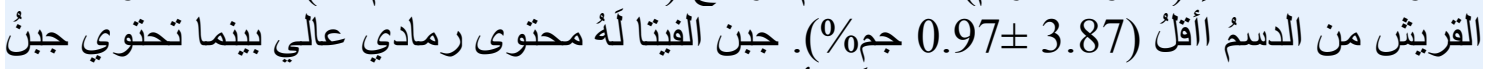

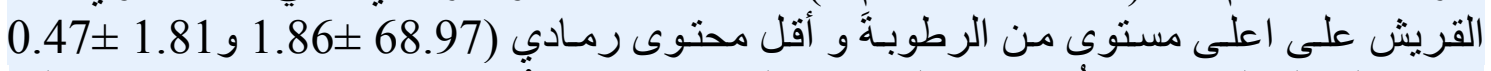

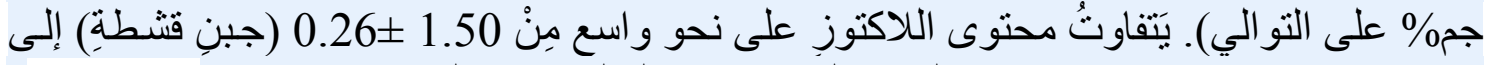

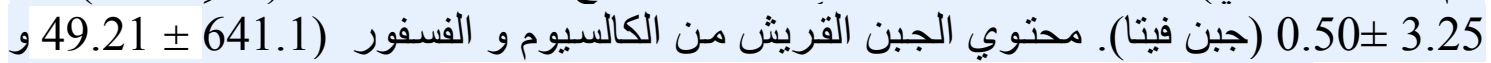

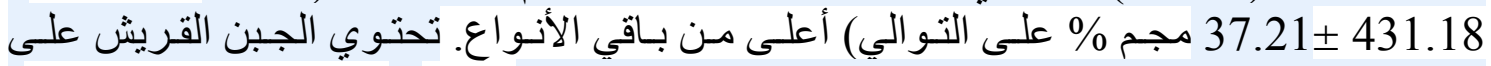

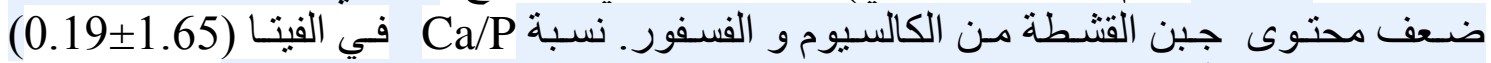

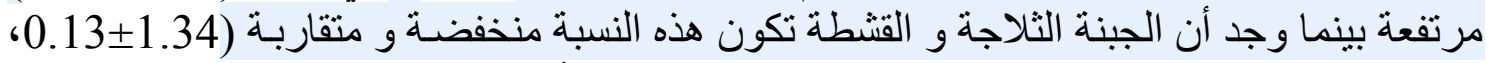

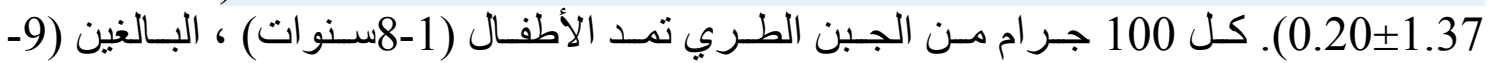

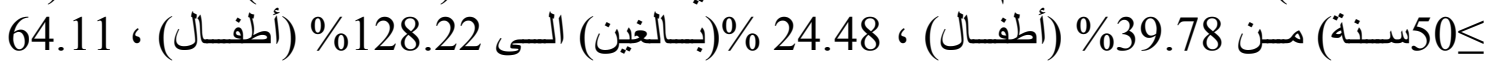
\%(بالغين) من احتياجتهم من الكالسيوم وذلك من الجبن القتطة و الجبن القريش على التو الي. 